\title{
Changes in oestrone sulphate concentrations in peripheral plasma of Pony mares associated with follicular growth, ovulation and early pregnancy
}

\author{
D. W. Makawiti, W. E. Allen* and M. J. Kilpatrick† \\ Department of Obstetrics and Gynaecology, King's College Hospital Medical School, Denmark Hill, \\ London SE5 and *Department of Surgery and Obstetrics, Royal Veterinary College, \\ Hawkshead Lane, North Mymms, Hatfield, Herts, U.K.
}

\begin{abstract}
Summary. A simple and rapid $(<2 \mathrm{~h})$ immunoassay method has been developed based upon a novel separation technique called LIDIA (Ligand Differentiation Immunoassay), enabling direct estimation of the concentration of oestrone sulphate in ethanolic extracts of blood plasma. An antiserum raised against oestrone-3-glucuronyl-BSA was used which showed a higher cross-reaction with the sulphate than the glucuronide metabolite. The assay had a sensitivity of $5 \cdot 2 \mathrm{pg} /$ tube and acceptable inter- $(<18 \%)$ and intra- $(<8.5 \%)$ assay precision. Analysis of samples of peripheral venous plasma obtained daily from Pony mares showed that the mean concentration of oestrone sulphate started to rise from a baseline value $(<300 \mathrm{pg} / \mathrm{ml})$ at 6 days and reached a peak $(>850 \mathrm{pg} / \mathrm{ml})$ at 2 days before follicular rupture as determined by rectal palpation. Progesterone concentrations only started to rise above baseline $(<0.5 \mathrm{ng} / \mathrm{ml})$ on the day of ovulation and reached a peak 8 days later. Analysis of samples obtained during the first 30 days of pregnancy showed that there was no increase in oestrone sulphate at the time oestrus would have been expected had the mares not conceived.
\end{abstract}

\section{Introduction}

The mare is seasonally polyoestrous with the initiation of ovarian activity being associated with increasing daylength (Cole \& Cupps, 1977). Under natural environmental conditions the first oestrus is often anovulatory with the follicle undergoing atresia (Trum, 1950). After cycles are established the period between lysis of the corpus luteum of one cycle and the next ovulation is variable due to the unpredictable growth rate of the follicle. Since matings close to and before ovulation are the most fertile (Van Rensburg \& Van Heerden, 1953; Allen, 1981), and in order to reduce the number of matings per mare to a minimum, it is important that a reliable method be found for monitoring follicular maturation and predicting the time of ovulation.

As in other domestic species some of the main secretory products of the equine preovulatory follicle are oestrogens and the blood concentration of total oestrogens increases during the period of sexual receptivity (Nett, Holtan \& Estergreen, 1973). Plotka, Foley, Witherspoon, Schmoller \& Goetsch (1975) have shown that the concentration of unconjugated oestrogen in peripheral plasma remains unchanged at $50 \mathrm{pg} / \mathrm{ml}$ throughout the periovulatory period. However, Noden, Oxender \& Hafs (1975) found that androstenedione and oestradiol-17 $\beta$ reach peak values 2 days before

† Present address: Glaxo Animal Health Ltd, Biological Research Department, Breakspear Road South, Harefield, Uxbridge, Middx UB9 6LS, U.K. 
ovulation although no change in the basal level of oestrone concentration $(9-12 \mathrm{pg} / \mathrm{ml})$ was detected. A preovulatory rise of dehydroepiandrosterone in the mare has been reported (Rance, Park, Rowe \& Dean, 1976) although this is thought to be of adrenal origin. Eraldo, Bono \& De Fanti (1973) and Pattison, Chen, Kelly \& Brandt (1974) have also shown that oestradiol-17 $\beta$ concentrations in plasma reach a peak $24-72 \mathrm{~h}$ before ovulation and thereafter fall slowly. However, total oestrogen (conjugated and unconjugated) concentrations consistently reach a peak $48 \mathrm{~h}$ before ovulation and then decline rapidly (Palmer \& Terqui, 1977) and the conjugated oestrogens are present in 100-fold higher concentrations than the unconjugated forms. There is additional evidence that in equine pregnancy oestrone is present largely in the form of the sulphate (Cox, 1975).

In this study we have utilized the ability of an antiserum raised against oestrone-3-glucuronide to cross-react with oestrone-3-sulphate, and we have correlated the changes in peripheral plasma concentrations of this metabolite with an assessment of follicular maturation obtained by rectal palpation.

\section{Materials and Methods}

\section{Animals}

Eleven Pony mares were used. Samples of heparinized peripheral venous blood were obtained daily between $08: 00$ and 10:00 h throughout 12 oestrous cycles, and the first 30 days of 5 pregnancies. Immediately after collection, the blood samples were centrifuged at $4^{\circ} \mathrm{C}$, and the plasma was stored at $-20^{\circ} \mathrm{C}$ until required. The ovaries were examined per rectum after blood sampling and the location and size of ovarian follicles were recorded.

\section{Radioimmunoassay for oestrone-3-sulphate}

Assay. Plasma samples $(300 \mu \mathrm{l})$ were mixed with $600 \mu \mathrm{l}$ absolute ethanol, and centrifuged at $2000 \mathrm{~g}$ for $10 \mathrm{~min}$ to precipitate the protein. Aliquants $(200 \mu \mathrm{l})$ of the supernatant were transferred to glass assay tubes, evaporated to dryness in a vacuum oven, and reconstituted in $100 \mu 1$ assay buffer $(0 \cdot 1 \mathrm{M}$-Tricine-buffered saline, $\mathrm{pH} 7)$. Serial dilutions of authentic standard (oestrone-3sulphate, sodium salt; Sigma Chemical Co., Poole, Dorset, U.K.) were also prepared in buffer over the range 250 to $7.8 \mathrm{pg}$ oestrone sulphate $/ 100 \mu \mathrm{l}$ buffer.

To the samples and standards were added $100 \mu \mathrm{l}\left[6,7-{ }^{3} \mathrm{H}\right]$ oestrone-3-sulphate (containing 20000 d.p.m., sp. act. $50 \mathrm{Ci} / \mathrm{mmol}$; New England Nuclear, Southampton, U.K.) and sufficient antiserum (1:13000 dilution, anti-oestrone-3-glucuronyl-bovine serum albumin) to give approximately $60 \%$ binding of ${ }^{3} \mathrm{H}$ ligand when incubations were carried out in the absence of unlabelled sulphate.

After incubation for $30 \mathrm{~min}$ at room temperature $\left(21-25^{\circ} \mathrm{C}\right), 50 \mu$ enzyme solution $(8 \mathrm{mg} / \mathrm{ml}$, $24.6 \mathrm{U} / \mathrm{mg}$ ) (arylsulphatase Type H-1, from Helix pomatia, Sigma) were added to each tube which was incubated at room temperature for a further $30 \mathrm{~min}$. Separation of bound from free ligand was achieved by addition of $1 \mathrm{ml}$ scintillation fluid ( $5 \mathrm{~g} \mathrm{PPO}, 1 \%$ ethanol, $99 \%$ toluene, $\mathrm{v} / \mathrm{v}$ ). Thorough mixing of the tube contents resulted in the preferential removal of the hydrolysed $\left[{ }^{3} \mathrm{H}\right]$ oestrone from the aqueous to the organic phase. That proportion of $\left[{ }^{3} \mathrm{H}\right]$ oestrone-3-sulphate which was bound to the antibody was protected from enzymic hydrolysis and therefore remained in the aqueous phase. Counting of the tube contents in a beta scintillation counter (for $1 \mathrm{~min} /$ tube) resulted in only the radioactivity in the organic phase being recorded. This mode of separation has been termed LIDIA (Ligand Differentiation Immunoassay) and is the subject of U.K. Patent Application No. 8118291 (Publication No. 2078370) and foreign patent applications.

Calibration curve and reproducibility. The mean of the percentage of oestrone sulphate bound over the range of the calibration curve is shown in Text-fig. 1(a). The mean sensitivity of the assay (denned as the response at twice the s.d. of $\left.B_{0}\right)$ was $5 \cdot 2 \mathrm{pg} /$ tube $(n=5)$ which is equivalent to $80 \cdot 0$ 


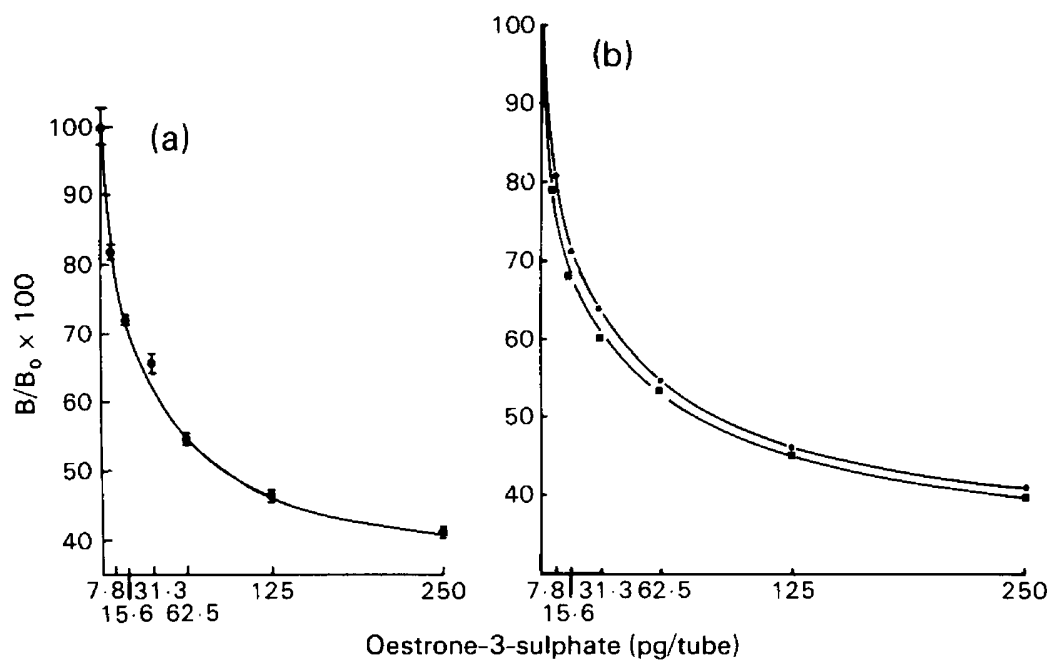

Text-fig. 1. The oestrone sulphate calibration curve. (a) The standard curve (mean \pm s.e.m.) for values from 5 different assays. As the free fraction has been counted the dose-response has been transformed by calculating B/Bo. (b) Comparison between ether-extracted standard (O) and non-extracted standard $(\mathbb{D})$ curves.

$\mathrm{pg} / \mathrm{ml}$ plasma. The mean coefficient of correlation for the seven-point calibration curve was $0.994 \pm 0.0038(n=19)$.

The intra-assay variation was assessed by measuring 20 replicates at two concentrations and was $7.6 \%$ at $658 \mathrm{pg} / \mathrm{ml}$ and $8.2 \%$ at $440 \mathrm{pg} / \mathrm{ml}$. The inter-assay variation was $17.6 \%$ over 18 assays at a dose level of $431 \mathrm{pg} / \mathrm{ml}$. There was no evidence of drift within the assay as observed from the plot of concentration versus sample number for intra-assay variation and from the quality control samples. This means that although the enzyme and the substrate are in the same aqueous phase for short counting periods the partition is stable enough not to affect the overall results.

Antiserum specificity. The cross-reactivity of the anti oestrone-3-glucuronide serum was defined as the amount of steroid required to give a $50 \%$ decrease in binding of $\left[{ }^{3} \mathrm{H}\right]$ oestrone-3-sulphate. There was approximately a 2 -fold higher affinity for oestrone sulphate ( $73 \mathrm{pg} /$ tube) than for the glucuronide (130 pg/tube), whilst oestrone alone cross-reacted to the same extent as the sulphate $(85$ $\mathrm{pg} /$ tube). There was no cross-reaction with oestradiol, oestriol or the equine oestrogens $(>25000$ $\mathrm{pg} /$ tube). The value with oestradiol-17 $\beta, 3$-glucuronide was $>5000 \mathrm{pg} / \mathrm{tube}$.

Quantitative recovery of oestrone sulphate from mare plasma. Plasma samples $(20 \mu \mathrm{l})$ containing $50,100,200$ or $400 \mathrm{pg}$ oestrone sulphate were added to $350 \mu \mathrm{l}$ of a plasma pool containing one of three low oestrone sulphate concentrations and assayed for oestrone sulphate in duplicate. The difference between the expected value and the obtained value is expressed as a percentage of the expected value. The mean \pm s.d. percentage differences for $50,100,200$ and $400 \mathrm{pg}$ added were $+4.9 \pm 0.9,+2 \cdot 8 \pm 0 \cdot 7,+1 \cdot 7 \pm 0.4$ and $+1 \cdot 3 \pm 0.6 \%$ respectively.

Stability of oestrone sulphate standard compound. Oestrone sulphate salts are known to be unstable and undergo hydrolysis to release oestrone. To check the degree of hydrolysis of the standard oestrone sulphate, two calibration curves were set up. Standard solutions were serially diluted and $100 \mu \mathrm{l}$ samples were placed into test tubes in duplicate. Samples in one set of the tubes were extracted with $1 \mathrm{ml}$ diethyl ether and snap frozen in solid $\mathrm{CO}_{2}$-cooled ethanol. The ether extract was discarded and the aqueous phase thawed. Tritiated oestrone sulphate $(100 \mu 1)$ and $100 \mu \mathrm{l}$ appropriately diluted antiserum were added and the assay carried to completion as described earlier. The near superimposition of the extracted and non-extracted calibration curves (Text-fig. 1b) shows that an insignificant amount of oestrone sulphate was hydrolysed. 
Radioimmunoassay for progesterone

The concentration of progesterone in plasma was determined according to the method of Matson, Tyler \& Collins (1981), using an antiserum raised to progesterone-1 $1 \alpha$-succinyl-bovine thyroglobulin, a standard calibration range from 0.012 to $0.75 \mathrm{ng} /$ tube, and $[1,2,6,7-$ ${ }^{3} \mathrm{H}$ ]progesterone (sp. act. $85 \mathrm{Ci} / \mathrm{mmol}$ ) as the ligand.

The interassay variation for the measurement of progesterone was $13 \cdot 1 \%$ at $6.3 \mathrm{ng} / \mathrm{ml}(11$ determinations). Replicate analysis (20 times) within one assay gave values for the intra-assay variation of $11.6 \%$ at a dose level of $3.8 \mathrm{ng} / \mathrm{ml}$.

\section{Results}

\section{Unconjugated oestrone assay}

Preliminary investigations were performed to ascertain whether it was possible to measure the unconjugated form of oestrone. Determination of oestrone in diethyl ether extracts of daily plasma samples from cyclic mares was performed according to the method of Matson et al. (1981), using the same antiserum prepared to oestrone-6-carboxymethyloxime-BSA. The only difference was that $200 \mu \mathrm{l}$ plasma samples were extracted with $1 \mathrm{ml}$ diethyl ether to obtain values that were within the range of the calibration curve. The results showed that the concentration of oestrone was very low $(13.23 \pm 0.67$ (s.e.m.) $\mathrm{pg} / \mathrm{ml} ; n=60$ ), and did not vary significantly throughout the oestrous cycle.

\section{Pattern of oestrone sulphate and progesterone concentrations}

The concentrations of oestrone sulphate and progesterone in daily samples of peripheral plasma from 3 oestrous cycles are shown in Text-fig. 2. Follicular development and an increase in oestrone sulphate concentration appeared to be closely correlated, although the size of the follicle and the magnitude of the peak were not associated. In one cycle (Text-fig. 2c) follicular growth was detected before luteolysis was complete and this may explain why ovulation occurred so quickly.

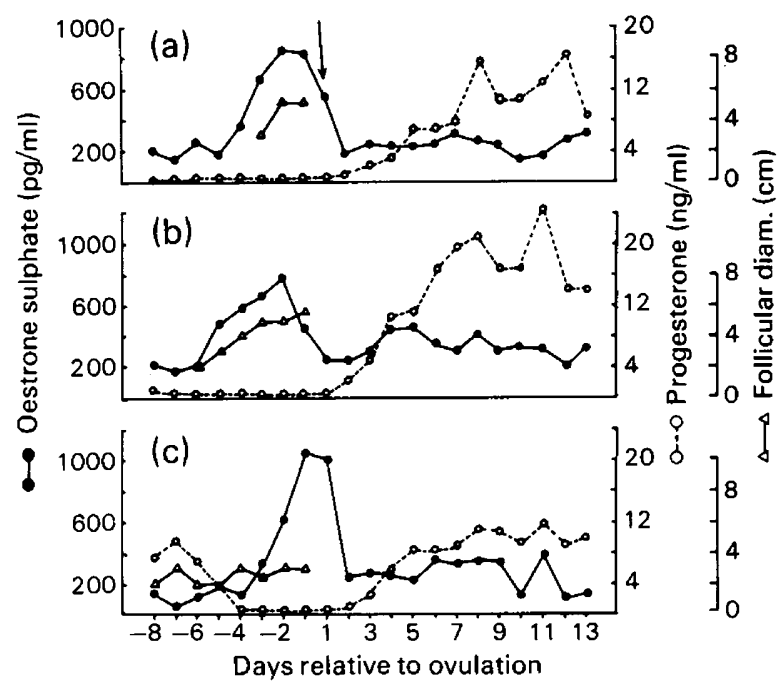

Text-fig. 2. The pattern of values for oestrone sulphate and progesterone in daily samples of peripheral plasma, and the follicular diameter as determined by rectal palpation in 3 Pony mares during one oestrous cycle. Ovulation (arrow) was on Day 1. 


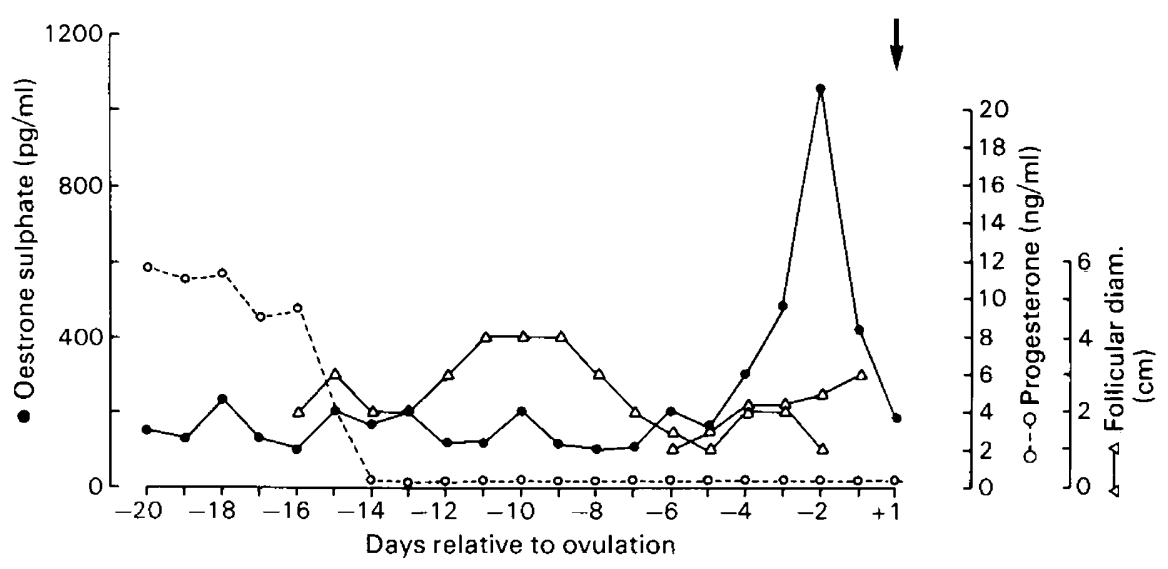

Text-fig. 3. The concentrations of oestrone sulphate and progesterone in daily plasma samples from a Pony mare during part of an oestrous cycle. The follicular diameter and day of ovulation (arrow) were determined by rectal palpation.

An unusual cycle is shown in Text-fig. 3. In this mare, luteolysis was followed by development of a follicle which did not rupture and subsequently became atretic; there was no associated rise in oestrone sulphate concentrations. A second follicle then started to develop in the opposite ovary, and was accompanied by increasing levels of oestrone sulphate which reached a peak $48 \mathrm{~h}$ before follicular rupture. The mare had been mated 12, 10, 8, 6, 4 and 2 days before the eventual ovulation and later examination showed that she had conceived.

The mean values for oestrone sulphate, progesterone and follicular diameter during 12 oestrous cycles are shown in Text-fig. 4. Plasma oestrone sulphate concentrations started to rise about 6 days before ovulation from a baseline value of $264 \pm 39 \mathrm{pg} / \mathrm{ml}$ (mean \pm s.e.m.), reaching a peak of $863 \pm 150 \mathrm{pg} / \mathrm{ml} 2$ days before ovulation. The concentrations then fell to near base-line levels by 1 day after follicular rupture. No rise was observed in pregnant mares at the expected time of ovulation if conception had not occurred (Text-fig. 5).

Progesterone values were $<0.5 \mathrm{ng} / \mathrm{ml}$ during the follicular phase and started to rise on the day of ovulation reaching a peak of $13.3 \pm 1.3 \mathrm{ng} / \mathrm{ml}$ (mean \pm s.e.m.) 8 days later. In non-pregnant

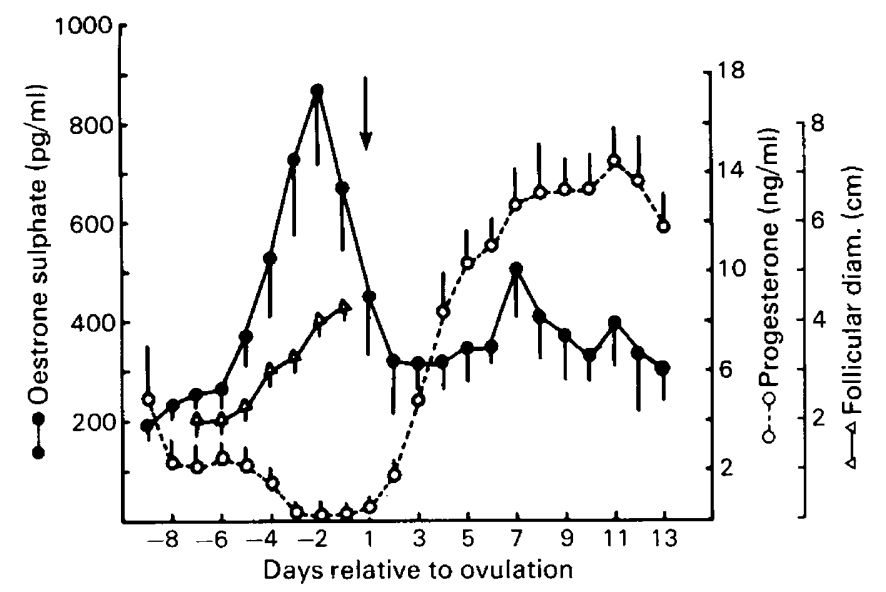

Text-fig. 4. The mean ( \pm s.e.m.) concentrations of oestrone sulphate and progesterone in daily samples of peripheral blood, and the mean ( \pm s.e.m.) follicular diameter as determined by rectal palpation of 7 Pony mares during 12 oestrous cycles. Ovulation indicated by arrow. 


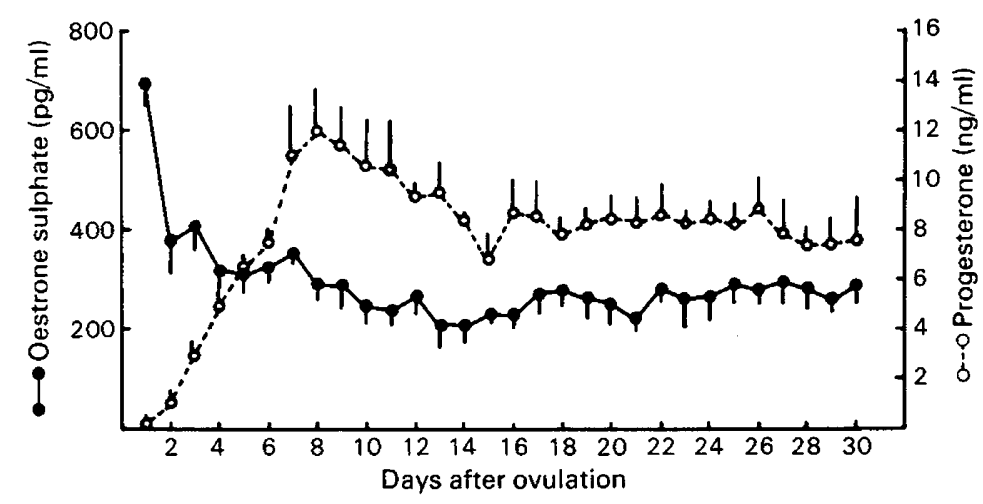

Text-fig. 5. The mean ( \pm s.e.m.) concentrations of oestrone sulphate and progesterone in daily samples of peripheral blood in 5 Pony mares during the first 30 days of pregnancy.

mares luteolysis occurred 14-15 days after ovulation; in those animals that conceived there was a slight decrease in progesterone concentrations at this time (Text-fig. 5) and values were maintained at about $8 \mathrm{ng} / \mathrm{ml}$ for the remainder of the 30-day study. This decrease was not statistically significant $(P>0.05)$ when peak values (Day 8$)$ were tested against values on Days 10,11 and 12 .

\section{Discussion}

The measurement of conjugated forms of oestrogens has been shown to be useful in monitoring ovarian function in man (Branch, Collins \& Collins, 1982) and non-human primates (Lasley, Hodges \& Czekala, 1980). In the mare, plasma conjugated oestrogens are present in 100-fold higher concentrations than the unconjugated forms (Palmer \& Terqui, 1977) and oestrone sulphate may well be a useful index for monitoring follicular development. Previous methods of measuring oestrone sulphate have involved lengthy hydrolysis and extraction procedures (Palmer \& Terqui, 1977). Even when direct measurements of oestrone sulphate have been achieved without prior hydrolysis there have still been up to three extraction steps (Wright, Collins, Musey \& Preedy, 1978). However, Saba \& Hattersley (1981) have indicated that certain antisera raised to oestrone-3glucuronide have a high degree of cross-reaction to oestrone-3-sulphate, thus enabling a direct estimation of oestrone sulphate in plasma to be made without hydrolysis. Utilization of this finding in conjunction with a novel separation process developed in this laboratory has enabled a rapid immunoassay for oestrone sulphate to be developed which is completed in about $2 \mathbf{h}$.

In general oestrone sulphate concentrations in peripheral plasma in mares increased in proportion to the size of the dominant follicle (except in one case, (Text-fig. 2c), although this may have been due to misleading information from rectal palpation) and is therefore associated with some stage of follicular development. This positive correlation continued until $24-48 \mathrm{~h}$ before follicular rupture, but then oestrone sulphate concentrations fell rapidly even though follicular size was maintained. The peak value of the metabolite did not relate significantly to the size of the follicle.

In the horse the material which is assayed as $\mathrm{LH}$ rises gradually from the time that behavioural oestrus is detected, reaches a peak on or after the day of ovulation and then gradually declines over the next 2-3 days (Whitmore, Wentworth \& Ginther, 1973; Pattison et al., 1974; Noden et al., 1974, 1975). The concomitant measurement of LH and oestrone sulphate will be necessary to elucidate the temporal relationship between these two hormones.

Unlike the pig, in which plasma oestrone sulphate concentrations significantly increase from the 16th day of gestation, and reach a peak between 23 and 30 days (Robertson \& King, 1974), there 
is no evidence that a similar rise exists up to the 30th day of gestation in the mare (Text-fig. 5). Therefore, in mares which are pregnant, the analysis of blood samples taken from Days 17-20 after ovulation will show low levels of oestrone sulphate $(<350 \mathrm{pg} / \mathrm{ml})$ and elevated levels of progesterone $(>7 \mathrm{ng} / \mathrm{ml})$. This concomitant estimation of both oestrone sulphate and progesterone may increase the accuracy of the hormonal detection of pregnancy at this stage of gestation.

The development of a useful monitoring test for follicular development, ovulation and early pregnancy in any domestic animal requires that the procedure be simple, rapid and can be performed on site. Although the ligand differentiation immunoassay for oestrone sulphate fulfils the first two criteria it still necessitates the use of a radioactive ligand.

We thank Mr G. J. Barnard and Professor W. P. Collins (King's College Hospital Medical School) for devising and discussing the principles of LIDIA; Dr P. Samarawajeewa (Courtauld Institute of Biochemistry, The Middlesex Hospital Medical School, London) for donating the antiserum to oestrone-3-glucuronide; and Miss P. Melville (Royal Veterinary College) for skilled zootechnical assistance. D.M.W. is in receipt of a Research Training Grant in Human Reproduction from the World Health Organisation and M.J.K. received a research fellowship supported by Amersham International Ltd.

\section{References}

Allen, W.E. (1981) Fertility in pony mares after postovulation service. Equine vet. J. 13, 134-135.

Branch, C.M., Collins, P.O. \& Collins, W.P. (1982) Ovulation prediction: changes in concentrations of urinary estriol-3-glucuronide, estradiol-17 $\beta$-glucuronide and estriol-16 $\alpha$-glucuronide during conceptional cycles. J. Steroid Biochem. 16, 345-347.

Cole, H.H. \& Cupps, P.T. (Eds) (1977) Reproduction in Domestic Animals, 3rd edn, pp. 402-403. Academic Press, New York.

Cox, J.E. (1975) Oestrone and equilin in the plasma of the pregnant mare. J. Reprod. Fert., Suppl. 23, 463468.

Eraldo, S., Bono, G. \& De Fanti, C. (1973) Variations in plasma oestrogen concentrations during the mare's oestrous cycle. Atti Soc. ital. Sci. vet. 27, 285-291.

Lasley, B.L., Hodges, J.K. \& Czekala, N.M. (1980) Monitoring the female reproductive cycle of great apes and other primate species by determination of oestrogen and LH in small volumes of urine. $J$. Reprod. Fert., Suppl. 28, 121-129.

Matson, P., Tyler, J.P. \& Collins, W.P. (1981) Follicular steroid content and oocyte meiotic status after PMSG stimulation of immature hamsters. J. Reprod. Fert. 61, 443-452.

Nett, T.M., Holtan, D.W. \& Estergreen, V.L. (1973) Plasma estrogens in pregnant and postpartum mares. J. Anim. Sci. 37, 962-970.

Noden, P.A., Oxender, W.D. \& Hafs, H.D. (1974) Estrus, ovulation and plasma progesterone and luteinizing hormone after prostaglandin $\mathrm{F}_{2 \alpha}$ in mares. Proc. Soc. exp. Biol. Med. 45, 145-150.

Noden, P.A., Oxender, W.D. \& Hafs, H.D. (1975) The cycle of oestrus, ovulation and plasma levels of hormones in the mare. J. Reprod. Fert., Suppl. 23, 189-192.
Palmer, E. \& Terqui, M. (1977) The measurement of total plasma oestrogens during the follicular phase of the mare's oestrous cycle. Theriogenology 7, 331-338.

Pattison, M.L., Chen, C.L., Kelly, S.T. \& Brandt, G.W. (1974) Luteinizing hormone and estradiol in peripheral blood of mares during estrous cycle. Biol. Reprod. 11, 245-250.

Plotka, E.D., Foley, C.W., Witherspoon, D.M., Schmoller, G.C. \& Goetsch, D.D. (1975) Periovulatory changes in peripheral plasma progesterone and estrogen concentrations in the mare. Am. J. vet. Res. 36, 1359-1362.

Rance, T.A., Park, B.K., Rowe, P.H. \& Dean, P.D.G. (1976) A preovulatory rise of dehydroepiandrosterone in the mare measured by radioimmunoassay. $J$. Steroid Biochem. 7, 677-681.

Robertson, H.A. \& King, G.J. (1974) Plasma progesterone and oestrogens in the pig. J. Reprod. Fert. 40, $133-141$.

Saba, N. \& Hattersley, J.P. (1981) Direct estimation of oestrone sulphate in sow serum for a rapid pregnancy diagnosis test. J. Reprod. Fert. 62, 87-92.

Trum, B.F. (1950) The estrous cycle of the mare. Cornell Vet. 40, 17-23.

Van Rensburg, S.W.J. \& Van Heerden, J.S. (1953) Infertility in mares caused by ovarian dysfunction. Onderstepoort J. vet. Res. 26, 285-313.

Whitmore, H.L., Wentworth, B.C. \& Ginther, O.J. (1973) Circulating concentrations of luteinizing hormone during estrous cycles of mares as determined by radioimmunoassay. Am. J. vet. Res. 34, 631-636.

Wright, K., Collins, D.C., Musey, P.I. \& Preedy, J.R.K. (1978) A specific radioimmunoassay for oestrone sulphate in plasma and urine without hydrolysis. $J$. clin. Endocr. Metab. 47, 1092-1098. 